\title{
Estimation of HCV Test in Diagnosis for Chronic Hepatitis C Virus
}

\author{
Soon-Mo Jang, Byoung Seon Yang \\ Department of Medical Laboratory Science, Jinju Health College, Jinju, Korea
}

\section{만성 C형 간염바이러스 진단에 있어서 HCV검사법의 평가}

\author{
장순모, 양병선 \\ 진주보건대학교 임상병리과
}

\begin{abstract}
To determine the clinical utility of an immunoblot test and RT-PCR-hybridization test, 160 samples from patients with a chronic HCV infection were analyzed by two tests. A total of 133 samples out of 150 positive samples were positive by RT-PCR-hybridization. The true positive rate of the immunoblot tests and the concordance rate of the two tests was $88.6 \%$ and $89.3 \%$, respectively. Serotyping and genotyping were performed to evaluate the distribution of the HCV subtype in Korean isolates. HCV serotypes 1 and 2, and genotypes $1 \mathrm{~b}$ and $2 \mathrm{a}$ were the most common sources of HCV infections in this group. In 49 cases studied with the serotypes and genotypes, serotypes 1 and 2 were $57.1 \%$ and $42.9 \%$, respectively. Genotypes $1 \mathrm{~b}, 1 \mathrm{~b} / 2 \mathrm{~b}, 2 \mathrm{a}, 2 \mathrm{a} / 2 \mathrm{c}$, and $2 \mathrm{~b}$ were $51.0 \%$, $2.0 \%, 34.7 \%, 8.2 \%$, and $4.1 \%$, respectively. This study shows that immunoblot tests are more useful for screening HCV infections. The RT-PCR-hybridization test confirmed the HCV infection in patients with positive immunoblot test results. The serotype test is preferred over the genotype test for monitoring the progression or response to treatment. On the other hand, there were no significant differences in the response to an $\alpha$-interferon treatment of HCV infection with serotype type 1 or type 2 in Korea.
\end{abstract}

Key words: Hepatitis C virus, Immunoblot, RT-PCR-hybridization

This is an Open Access article distributed under the terms of the Creative Commons Attribution Non-Commercial License (http://creativecommons.org/licenses/by-nc/4.0) which permits unrestricted non-commercial use, distribution, and reproduction in any medium, provided the original work is properly cited.

Copyright $\odot 2018$ The Korean Society for Clinical Laboratory Science. All rights reserved.
Corresponding author: Byoung Seon Yang Department of Medical Laboratory Science, Jinju Health College, 51 Uibyeong-ro, 52655 Jinju, Korea

Tel: 82-55-740-1821

Fax: 82-55-743-3010

E-mail: ybseon@jhc.ac.kr

Received: July 16, 2018

Revised $1^{\text {st: }}$ : August 14, 2018

Revised 2 ${ }^{\text {nd. }}$ : August 27, 2018

Accepted: August 29, 2018

\section{서 론}

C형 간염 바이러스(Hepatitis C Virus, HCV)는 크기가 80 $\mathrm{nm}$ 이하의 작은 바이러스로 1989년 Choo 등[1, 2]에 의해 게놈 의 구조가 밝혀졌는데 약 10,000 개의 뉴클레오티드와 약 3,000 개의 아미노산을 가진 단일가닥 RNA바이러스이다. 1989년 Kuo 등[3]에 의하면 유전자 재조합법으로 클로닝된 NS3 일부 와 NS4 일부 바이러스 항원에 대한 항체 진단법이 개발되어 $\mathrm{HCV}$ 진단에 사용하였으며 현재는 제 3 세대 효소면역 측정법이 이용되고 있다. HCV는 수혈 후 비A 비B형 간염의 90 95\%를
일으키는 원인으로 알려져 있으며 약 $9,400 \mathrm{bp}$ 크기의 양성가 닥 RNA 게놈을 가지고 있다. Fraviviridae과의 flavivirus 및 pestivirus와 유사한 구조부위의 core (C)단백, envelope1 (E1)단백, E2/nonstructural protein 1 (NS1)단백과 비구조부 위의 NS2, NS3, NS4 및 NS5 부위 단백을 합성한다. HCV 감염 의 진단은 혈청 항체를 검출하는 방법과 reverse-transcription polymerase chain reaction (RT-PCR)을 이용하여 바이러스 의 RNA를 직접 검출하는 방법이 있다. 그리고 간접적으로 alanine aminotransferase (ALT)의 활성을 보거나 직접적으로 간 생검이 이용될 수 있으나 두 방법 모두 선별검사에는 적합한 
방법이 될 수 없다. 항체검사는 항체 형성기간 동안에는 진단이 어려우며, 환자가 감염 후 회복되었는지 현재 바이러스 혈증이 있는지를 구분하기 어렵다[4]. 최근 $\mathrm{HCV}$ 정성 및 정량검사에 이용하는 RT-PCR방법과 RT-PCR-Hybridization방법으로 보다 표준화되어 일상 검사에서 나타나는 오차를 많이 개선시 킨 것으로 보고 있다[5]. HCV의 유전자 아형간에 c100-3 단백 에 대한 제1세대 anti-HCV ELISA 및 제2세대 재조합 immunoblot방법에 대한 반응에서 차이가 있음이 밝혀졌다. 최근에는 c 33c 및 c22 단백에 대한 양성도가 다른 것이 알려짐 에 따라 혈청학적 아형 검사법이 고안되었는데 이것은 아형 특 이 아미노산에 대한 항체를 효소면역법으로 검출하는 방법이 다. 현재 $\mathrm{HCV}$ 유전자 배열에 기초한 $\mathrm{HCV}$ 유전자형의 분포 양상 은 미국, 유럽, 아프리카 및 아시아지역을 대상으로 시행한 연구 보고가 많이 있으나 $[6,7]$. 국내에서는 아직 많은 자료가 축적되 어 있지 않아이에 대한 다각적인 연구가 필요한 실정이다. 한편 $\mathrm{HCV}$ 가 발견되기 이전에 interferon (IFN)은 만성 비A 비B형 간 염의 치료에 효과적으로 사용되어 왔으며 $\mathrm{HCV}$ 의 진단체계가 성립된 이후 많은 연구자들이 IFN의 효용성과 $\mathrm{HCV}$ 표지자 와 의 관련성을 검토하여 왔다[8]. $\mathrm{HCV}$ 의 임상증상은 가벼운 경우 가 대부분이나 간조직 검사에서 반수 가량이 만성 활동성 간염 이 발견되고 $20 \%$ 이상에서 20 년 내 간경변증으로 진행된다. 그 리고 간암 발생율이 연 1 4\%인 것으로 알려져 있어 C형 간염 은 적절히 치료되어야 한다[9]. C형 간염은 치료가 어려우며 IFN으로 치료하더라도 장기적으로 치유효과가 $25 \%$ 이하이다. 따라서 면역학적 상태를 파악하고 IFN에 유효한 반응을 나타내 는 환자를 파악하는 것이 C형 간염환자의 관리에 유익할 것이 다. 이에 본 연구는 HCV검출에 immunoblot방법과 RT-PCRhybridization 법을 비교하고 혈청형과 유전형을 분석한 후 IFN 치료효과와의 관련성을 규명하는 것도 의의 있는 것으로 사료 되어 본 연구를 시행하였다.

\section{재료 및 방법}

\section{1. 재료}

부산지역 종합병원에서 C형 간염 의심으로 immunoblot방 법 검사결과 양성 150예 및 음성 검체 10예 총 160예를 RTPCR-hybridization법을 실시하여 양자의 성적을 비교 하였다. 두 방법에서 양성인 검체 133예 중 혈청형과 유전자형이 모두 검출 될 수 있었던 49예를 대상으로 아형을 비교하였으며 IFN 치료 효과를 검정하였다.

\section{2. 방법}

\section{1) HCV 검출}

(1) Immunoblot방법

Immunoblot방법(Genelab, Singapore)은 HCV genome 의 capsid, NS3, NS4, NS5 영역으로 나오는 core, NS3-1, NS3-2, NS4, NS5의 5개의 재조합 펩티드가 있는 nitrocellulose strip을 희석된 혈청과 반응시켰다. 그 후 비 결합된 물질의 제거 를 위해 세척하고 정제된 anti-human $\operatorname{lgG}$ 를 넣어 반응시켰다. 비 결합 물질을 세척에 의해 제거하고 판독 기준은 시약 회사지 침에 따라 실시하였다.

(2) RT-PCR-Hybridization법

Amplicor PCR diagnostics HCV Assay (Roche Co, Swiss) 를 이용하여 검체 전처리, 역전사, $\mathrm{PCR}$ 증폭, 교잡반응 및 검출 의 순서로 실시하였다. 환자 검체와 대조액 검사에 필요한 $\mathrm{PCR}$ 튜브에 master mix $50 \mu \mathrm{L}$ 를 넣어 $2 \sim 8^{\circ} \mathrm{C}$ 에 보관하였다. 각 환 자 혈청과 대조액을 위한 lysis 완충액 $400 \mu \mathrm{L}$ 를 $1.5 \mathrm{~mL}$ 튜브에 가하고 표시한 후, 양성 및 음성 대조 튜브에 $100 \mu \mathrm{L}$ 의 $\mathrm{HCV}$ negative plasma (human)를 넣고 진탕하였다. 그리고 음성 대 조 튜브에 $\mathrm{HCV}(-)$ 대조액 $50 \mu \mathrm{L}$ 를, 양성대조 튜브에는 $\mathrm{HCV}(+)$ 대조액 $50 \mu \mathrm{L}$ 를 각각 넣은 후 진탕하였다. 나머지 환자 튜브에 환자 혈청 또는 혈장 검체 $100 \mu \mathrm{L}$ 를 넣고 진탕한 후 모든 튜브를 $60^{\circ} \mathrm{C} \pm 2{ }^{\circ} \mathrm{C}$ 에서 10 분간 배양하고 잘 혼합하였다. 각 튜 브에 이소프로필 알콜 $500 \mu \mathrm{L}$ 를 넣고 진탕한 다음 2 분간 실온 에서 배양한 후 실온에서 $12,500 ~ 16,000 \times \mathrm{g}$ 로 15 분간 원심 분리하였다. 상층액을 버린 후 각 튜브에 $70 \%$ 에탄올을 가하고 섞은 후 실온에서 최대속도로 5 분간 원심 분리하여 상층액을 제 거하고 희고 뚜렷한 침전을 육안으로 확인 하였다. 그리고 $\mathrm{HCV}$ internal control $50 \mu \mathrm{L}$ 를 검체 희석병에 넣어 검체를 희석 후 희석된 검체 $1 \mathrm{~mL}$ 를 각 튜브에 넣어 반응 시켰다. $\mathrm{HCV} \mathrm{CDNA}$ 합 성을 위해 $5 \mu \mathrm{L}$ 의 RNA추출용액과 $100 \mathrm{pmol}$ 의 primer를 넣고 $90^{\circ} \mathrm{C} 2$ 분간 가열 한 후 $4^{\circ} \mathrm{C}$ 로 급속히 냉각 $\mathrm{RNA}$ 을 변성시켜 10 unit의 ribonuclease 억제제 및 200 unit의 역전사 효소를 넣어 $42^{\circ} \mathrm{C}$ 에서 30 분간 반응시키고 $95^{\circ} \mathrm{C}$ 에서 5 분간 가열하여 역전 사 반응을 종료하였다. $\mathrm{HCV} \mathrm{CDNA}$ 증폭을 위해 역전사 반응액 $30 \mu \mathrm{L}$ 와 PCR반응액 $20 \mu \mathrm{L}$ 를 혼합하여 최종량은 $50 \mu \mathrm{L}$ 로 하여 $\mathrm{PCR}$ 은 $50^{\circ} \mathrm{C} 5$ 분, $60^{\circ} \mathrm{C} 30$ 분 및 $95^{\circ} \mathrm{C} 1$ 분을 실시 한 후 $95^{\circ} \mathrm{C}$ 15 초 및 $60^{\circ} \mathrm{C} 20$ 초씩 2 회, $90^{\circ} \mathrm{C} 15$ 초 및 $60^{\circ} \mathrm{C} 20$ 초씩 38 회 실 시한 후 $72^{\circ} \mathrm{C}$ 에 15 분간 반응하였다. 농축 세척액을 증류수로 10 배 희석하여 세척액을 조제하고 잘 섞은 후 $\mathrm{HCV}$ hybridization buffer $100 \mu \mathrm{L}$ 를 각각의 well에 넣었다. 그리고 
변성된 증폭산물 $25 \mu \mathrm{L}$ 을 각 well에 넣은 후 덮개를 덮고 $37^{\circ} \mathrm{C}$ 에서 1 시간 반응시켰다. 이것을 5 회 세척한 후각 well에 avidin$\mathrm{HRP}$ conjugate $100 \mu \mathrm{L}$ 를 넣고 $37^{\circ} \mathrm{C}$ 에서 섞어 만든 working substrate를 각 well에 $100 \mu \mathrm{L}$ 씩 넣은 후 $450 \mathrm{~nm}$ 에서 흡광도 를 측정하여 양성 유무를 판정하였다.

\section{2) HCV 혈청형과 유전형}

(1) HCV serotyping 1-6 assay

HCV Serotyping 1-6 Assay kit (Murex Diagnostics, UK) 를 이용하여 제조회사의 설명서에 지시된 방법대로 ELISA측정 기(BRIO, Italy)를 사용하여 검사하였다. 결과 판정은 $\mathrm{H}$ well의 흡광도가 G well의 흡광도 보다 0.1 이상 크고 또한 가장 높은 흡광도를 나타낸 well의 흡광도가 H well의 흡광도의 0.4 배가 넘을 때만 신뢰성이 있는 결과로 판정하였다.

(2) Line probe에 의한 HCV 유전자 아형

Random primer로 $\mathrm{HCV}$ cDNA를 합성하였고, GeneAmp PCR system 9600 (McKinley scientific, USA) 에서 outer primer로 $94^{\circ} \mathrm{C} 30$ 초간 변성, $55^{\circ} \mathrm{C} 30$ 초간 접합, $72{ }^{\circ} \mathrm{C} 30$ 초간 확장 조건에서 30 회 실시하였다. PCR 산물 중 $1 / 10$ 을 취하여 inner primer로 같은 조건 하에서 nested PCR을 실시하였다. Nested PCR 산물 $10 \mu \mathrm{L}$ 를 type specific probe가 코팅된 strip 을 반응시켜 유전자형을 결정하였는데 INNO-LiPA HCV kit (Innogenetics, Belgium)에서 제시하는 방법대로 실시하였다.

Table 1. HCV immunoblot test and RT-PCR-hybridization

\begin{tabular}{cccc}
\hline \multirow{2}{*}{ RT-PCR-hybridization } & \multicolumn{3}{c}{ Immunoblot } \\
\cline { 2 - 4 } & Reactive & Nonreactive & Total \\
\hline Positive & 133 & - & 133 \\
Negative & 17 & 10 & 27 \\
Total & 150 & 10 & 160 \\
\hline
\end{tabular}

\section{3) IFN 치료 효과의 판정 기준}

IFN 치료 종료 후 정상화된 혈청 ALT 치의 지속과 함께 계속 적으로 음전화 된 $\mathrm{HCV} \mathrm{RNA}$ 가 존재하였을 때를 완전 관해 (complete)로 하였고 혈청 ALT 치는 계속 정상치를 지속하나 계속해서 $\mathrm{HCV}$ RNA가 양성으로 나타날 때를 불완전 관해 (noncomplete)로 평가하였으며 완전 관해와 불완전 관해에 해 당되지 않는 예를 무반응(none)으로 분류하였다.

\section{4) 통계분석}

SPSS 10.0 (SPSS Inc., Chicago, IL, USA)을 이용하였으며 immunoblot방법과 RT-PCR-hybridization법과의 비교, 혈 청형과 유전형의 치료반응 유무에 대한 검정은 $\chi^{2}$ test 또는 Fisher 확률 검정법으로 비교하였다. 혈청형과 유전형의 비교 는 일치율(concordance rate)을 조사하였으며, 유의수준은 0.05 이하로 하였다.

\section{결 과}

\section{1. $\mathrm{HCV}$ 검출}

$\mathrm{HCV}$ immunoblot 검사 양성인 검체 150 예와 대조군으로 음성인 검체 10예 총160예를 대상으로 RT-PCR-hybridization 법을 실시하여 두 방법을 비교한 것은 Table 1과 같다. 양성 150 예 중 133예만 RT-PCR-hybridization법에서 양성을 나타내 어 immunoblot방법의 진양성율은 $88.6 \%$ 를 나타내었으며 immunoblot방법에서 음성인 검체 10예 에서 RT-PCRhybridization 검사 결과 음성으로 나타났다.

\section{HCV 혈청형과 유전형}

HCV immunoblot법과 RT-PCR-hybridization법에서 양 자 양성을 나타낸 133예에 대하여 혈청형과 유전자형검사를 실 시하여 양자가 모두 검출되는 49예를 서로 비교한 것이 Table 2 이다. 혈청형 검사에서 총 49예 중 28예(57.1\%)가 1형, 21예

Table 2. Comparison between HCV genotype and serotype

\begin{tabular}{lccccccc}
\hline \multirow{2}{*}{ Genotype } & \multicolumn{7}{c}{ Seotype (No. of cases) } \\
\cline { 2 - 8 } & Type 1 & Type 2 & Type 3 & Type 4 & Type 5 & Type 6 & Total \\
\hline $1 \mathrm{~b}$ & 23 & 2 & - & - & - & - & 25 \\
$1 \mathrm{~b} / 2 \mathrm{~b}$ & 1 & - & - & - & - & - & 1 \\
$2 \mathrm{a}$ & 2 & 15 & - & - & - & - & 17 \\
$2 \mathrm{a} / 2 \mathrm{c}$ & 1 & 3 & - & - & - & - & 2 \\
$2 \mathrm{~b}$ & 1 & 1 & - & - & - & - & 49 \\
Total & 28 & 21 & - & - & & - & - \\
\hline
\end{tabular}

*Concordance rate $84.4 \%$. 
(42.9\%)가 2형을 나타났으며 유전자형 검사에서 $1 \mathrm{~b}$ 형이 25 예 (51.0\%), $1 \mathrm{~b} / 2 \mathrm{~b}$ 를 나타낸 예가 1 예(2.0\%), 2a형이 17예 (34.7\%), 2a/2c를 나타낸 예가 4예(8.2\%), 그리고 2b형이 2예 (4.1\%)를 나타났다.

\section{IFN 반응}

IFN 치료를 받았던 49예의 환자에 대한 유전형과 혈청형에 관한 치료 효과를 나타낸 것은 Tables 3, 4이다. 49환자 중 20예 (40.8\%)가 완전 관해를 나타내었으며 5예(10.2\%)가 불완전 관 해를 그리고 24예(49\%)가 치료에 무반응을 나타내었다. 유전형 불완전 관해를 나타낸 $1 \mathrm{~b}$ 형이 $60 \%, 2 \mathrm{a}$ 형이 $20 \%$ 를 나타났다.

\section{고 찰}

C형 간염 바이러스 감염은 수혈 받은 사람의 7 10\%에서 발 생하는 수혈의 비교적 흔한 합병증으로서 $\mathrm{HCV}$ 감염자 중 $50 \%$ 이상은 만성 간질환으로 이행되는 데 이중 $20 \%$ 정도는 만성 활 동성간염, 간경화 등에 걸리게 되고 간암 발생의 위험을 증가시 키게 된다[10]. C형 간염의 진단에 사용되고 있는 항체검사는 비교적 민감하고 특이적인 검사이지만 바이러스 항원에 대한 직접적인 검출은 RT-PCR방법을 사용했다[11]. 특히 C형 간염 은 항체 선별 검사로는 혈청전환 이전에 조기 진단이 어렵다는 문제점 외에도 현재까지의 항체 선별검사는 위양성율이 높아 전체적으로 진양성율이 낮은 단점을 갖고 있다. 1990년 van der Poel 등[12]이 처음으로 상업용 제 1세대 ELISA 시약을 이
용하여 anti-HCV를 검출하였으며, 이후 제 1세대 ELISA시약 의 민감도와 특이도를 더욱 향상시키기 위하여 c100-3항원에 $\mathrm{HCV}$ 구조 단백인 core와 비 구조 단백인 NS3/NS4가 추가된 제 2세대 anti-HCV ELISA 시약이 사용되었다. 최근 제 2세대 anti-HCV ELISA 시약이 가진 항원들에 비구조항원인 NS5 등 을 보완하여 위양성율을 크게 감소시킨 제 3세대 anti-HCV ELISA 시약이 개발되었고, 국내에서도 역시 몇 종류의 제 3세대 anti-HCV ELISA 시약이 개발되었다. 그러나 제조회사에 따라 유전자 재조합 기술과 바이러스 항원의 아미노산 구조 등에 차 이가 있어 동일 검체를 여러 가지 시약으로 동시에 검사하여도 시약에 따라 검출률에 차이가 있고 아직도 위양성을 완전히 배 제할 수 없다[4]. 본 연구에서 immunoblot방법과 RT-PCRhybridization법의 일치율은 $89.3 \%$ 로 높고 immunoblot방법 에서 음성은 모두 RT-PCR-hybridization법에서도 음성으로 나타났다. 따라서 $\mathrm{HCV}$ 감염이의심되는 환자는 우선 immunoblot 방법을 실시한 후, 그 결과에 따라 RT-PCR-hybridization법으 로 확진 하는 것이 좋겠다. 혈청형과 유전자형의 분류는 core 혹 은 NS5 부위의 변이를 기준으로 type1, 2, 3 및 4의 4가지형으 로 분류한 Okamoto 등[8] 분류와 E1 혹은 NS5 부위의 변이를 기준으로 type 1a, 1b, 1c, 2a, 2b, 2c, 3a, 3b, 4a, 5a 및 6a 등으 로 나눈 Simmonds 등[11]의 분류를 비롯하여 여러 학자마다 서로 다른 기준과 이름으로 분류되고 있어서 아형 비교연구에 어려움을 초래하여 왔으나, 현재에는 Simmonds 등에 의한 분 류가 국제적으로 인정되고 있다. 이러한 아형을 결정하는 방법 에는 core serotyping, NS4 serotyping, line probe assay,

Table 3. Response to $\alpha$-interferon treatment in 49 patients chronically infected HCV serotypes

\begin{tabular}{ccccc}
\hline \multirow{2}{*}{ HCV serotype } & No. of patients & \multicolumn{2}{c}{ No. of patients with given response } \\
\cline { 3 - 5 } & & Complete & Incomplete & None \\
\hline Type 1 & 28 & 9 & 5 & 14 \\
Type 2 & 21 & 11 & - & 10 \\
Total & 49 & 20 & 5 & 24 \\
\hline
\end{tabular}

${ }^{*} P<0.05$

Table 4. Response to $\alpha$-interferon treatment in 49 patients chronically infected with HCV genotypes

\begin{tabular}{ccccc}
\hline \multirow{2}{*}{ HCV genotype } & No. of Patients & \multicolumn{2}{c}{ No.(\%) of patients with given responses } \\
\cline { 3 - 5 } & 25 & Complete & Incomplete & None \\
\hline $\mathrm{lb}$ & 1 & 10 & 3 & 12 \\
$\mathrm{lb} / 2 \mathrm{~b}$ & 17 & - & 1 & 9 \\
$2 \mathrm{a}$ & 4 & 7 & 1 & 2 \\
$2 \mathrm{a} / 2 \mathrm{c}$ & 2 & 2 & - & 1 \\
$2 \mathrm{~b}$ & 49 & 1 & 5 & 24 \\
Total & & 20 & - & 1 \\
\hline
\end{tabular}


restriction fragment length polymorphism (RFLP) 및 core 부위에 대한 RT-PCR typing방법 등 여러 가지가 있다.

본 연구에서 133 예의 $\mathrm{HCV}$ 간 질환자를 대상으로 NS4 펩티 드를 이용한 혈청형 검출법을 실시한 결과 92예에서만 혈청형 을 결정할 수 있었으며, 나머지 41예에서는 결정할 수가 없었 다. 혈청형이 결정된 92예 중 43예에서 유전자형이 결정되지 않 았다. 133예에 대하여 혈청형과 유전자형검사를 실시하여 양자 가 모두 검출되는 49예 중 혈청형 검사에서는 28예(57.1\%)가 1 형을, 21 예(42.8\%)가 2형을 나타났다. 국내의 보고에서 $\mathrm{HCV}$ 감염자 중 1 형은 $57.4 \%, 2$ 형은 $42.6 \%$ 라고 보고하여 본 연구의 성적과 유사하였다[14]. HCV 혈청형의 분류 방법이 상이하여 직접 비교는 할 수 없으나 일본의 보고도 본 연구 성적과 유사하 였다[15]. McOmish 등[7]에 의하면 일본과 대만에서는 1형과 2 형이 주로 나타나는데 비하여 홍콩, 마카오 등에서는 1,2 형 및 4형이 특징적으로 나타난다고 보고하고 있다. 혈청형과 유전자 형이 결정된 49예에서 유전자형과 혈청형을 비교하면, 본 연구 에서는 두 방법 간의 일치율이 $85.7 \%$ 로 국내연구와 유사하였다 [14]. 외국과 국내성적의 차이는 아마 유전자형의 결정에 있어 서 밴드 판독의 차이와 검체 수의 적음에 기인되는 것으로 생각 된다. 특히 유전형의 검출과 혈청형의 비교에 있어서 $\mathrm{HCV}$ 혈청 형 검출법은 감염자의 체액성 면역반응으로 생성된 형 특이 항 체를 검출하여 간접적으로 $\mathrm{HCV}$ 유전자형을 추정하지만, line probe방법에 의한 유전자형 검사와 높은 일치율을 보였다. 그 리고 검사 시에 엄격한 검체 보전이 필요 없고, 특수한 기기 및 숙련된 기술이 필요 없이 자동화된 ELISA 기기의 사용으로 빠른 시간 내에 결과를 자동으로 검출해 낼 수 있는 장점을 가지고 있 어서 $\mathrm{HCV}$ 유전자형 추정의 일상검사에 유용한 것으로 사료된 다. 본 연구에서는 49 예의 환자에 대한 유전자형 검사에서 $1 \mathrm{~b}$ 형 이 25 예, $1 \mathrm{~b} / 2 \mathrm{~b}$ 를 나타낸 예가 1 예, $2 \mathrm{a}$ 형이 17 예, $2 \mathrm{a} / 2 \mathrm{c}$ 를 나타 낸 예가 4 예, 그리고 $2 \mathrm{~b}$ 형이 2 예를 각각 나타내어 대부분이 $1 \mathrm{~b}$ 와2a형을 나타내었으며 1a 형은 한 예도 없었다. 또한 IFN 치료 를 받았던 49환자 중 20 예가 완전 관해를 나타내었으며 5예가 불완전 관해를 그리고 24 예가 치료에 무반응을 나타내었다. 불 완전 관해 5예 (10.2\%)는 처음에는 혈청 ALT치는 정상 수치로 내려갔으나 HCV RNA가 음전화 되지는 않았다. 무반응 24예 중 12 예가 $1 \mathrm{~b}$ 형을 나타내었으며 9예가 2a 형이었다. 본 연구에 서는 HCV검출을 위한 검사법은 ELISA검사법보다는 Immunoblot 법이 우수하며, 확진검사로는 RT-PCR-hybridization법을 시 행하는 것을 추천한다. $\mathrm{HCV}$ 아형 분석은 방법의 신속성과 간편 성 등으로 혈청형 검사가 유용한 것으로 사료되며, 한국인의 혈 청형은 1 형, 2 형이 대부분이며, 유전자형은 $1 \mathrm{~b}, 2 \mathrm{a}$ 로 나타났다.
IFN 치료효과는 $50 \%$ 이하로 저조하였으며 형별에 따른 치료효 과 판정은 보다많은 검체에 따른 연구가 필요할 것으로 사료된다.

\section{요 약}

만성C형 간염환자 160 예를 대상으로 immunoblot방법과 RT-PCR-hybridization법을 실시하여 임상검사의 유용성을 알아보았다. 양성 150예 중 133예만 RT-PCR-hybridization 법에서 양성을 나타내어 immunoblot법의 진양성율은 $88.6 \%$ 를 나타났으며 두 방법 간의 일치율은 $89.3 \%$ 를 나타났다. 한국 인의 $\mathrm{HCV}$ 아형을 알기 위하여 혈청형과 유전형을 실시하였다. $\mathrm{HCV}$ 혈청형 1형과 2형 그리고 $1 \mathrm{~b}$ 와 $2 \mathrm{a}$ 유전형이 가장 많은 C형 간염 감염원으로 나타났다. 49예를 혈청형과 유전형을 서로 비 교한 결과, 혈청형 검사에서 28예(57.1\%)가 1형, 21예(42.9\%) 가 2형으로 나타났으며 유전자형 검사에서 $1 \mathrm{~b}$ 형이 25예 (51.0\%), 1b/2b를 나타낸 예가 1예(2.0\%), 2a형이 17예 (34.7\%), 2a/2c를 나타낸 예가 4예(8.2\%), 그리고 2b형이 2예 (4.1\%)로 나타났다. 본 연구에서는 $\mathrm{HCV}$ 간이검출법으로는 immunoblot방법이 유용하며, immunoblot방법 양성 확진검 사로는 RT-PCR-hybridization법을 실시하였다. 혈청형이 C 형간염의 치료 나 진행과정을 관찰하기 위해서는 유전형보다 유용하나 인터페론 치료효과는 1형과 2형 혈청형별에 따라 차 이를 보이지 않았다.

Acknowledgements: None

Conflict of interest: None

\section{REFERENCES}

1. Choo QL, Weiner AJ, Overby LR, Kuo G, Houghton M, Bradley DW. Hepatitis $C$ virus: the major causative agent of viral non-A, non-B hepatitis. Br med Bull. 1990;46:423-441.

2. Choo QL, Kuo G, Weiner AJ, Overby LR, Bradley DW, Houghton M. Isolation of a cDNA clone derived from a blood-borne non-A, non-B viral hepatitis genome. Science. 1989;244: 359-362.

3. Kuo G, Choo QL, Alter HJ, Gitnick GL, Redeker AG, Purcell RH, et al. An assay for circulating antibodies to a major etiologic virus of human non-A, non-B hepatitis. Science. 1989;244: 362-364.

4. Tanaka E, Kiyosawa K, Nakatsuji Y, Inoue Y, Miyamura T, Chiba J, et al. Clinical significance of antibodies to nonstructural and core proteins of hepatitis $\mathrm{C}$ virus in post transfusion hepatitis patients during long-term follow-up. J med Virol. 1993;39:318-324. 
5. Zeuzem S, Rüster B, Roth WK. Clinical evaluation of a new polymerase chain reaction assay (Amplicor HCV) for detection of hepatitis C virus. J Gasteroenterol. 1994;32:342-347.

6. Inchauspe G, Zebedee S, Lee DH, Sugitani M, Nasoff M, Prince AM. Genomic structure of the human protype strain H of hepatitis C virus: comparison with American and Japanese isolates. Proc Natl Acad Sci. 1991;88:10292-10296.

7. McOmish F, Yap PL, Dow BC, Follett EA, Seed C, Keller AJ, et al. Geographical distribution of hepatitis $\mathrm{C}$ virus genotypes in blood donors: an international collaborative survey. J Clin Microbiol. 1994;32:884-892.

8. Okamoto H, Okada S, Sugiyama Y, Kurai K, Iizuka H, Machida A, et al. Nucleotide sequence of the genomic RNA of hepatitis $C$ virus isolated from a human carrier: comparison with reported isolates for conserved and divergent regions. J Gen Virol. 1991;72:2679-2704.

9. Mita E, Hayashi N, Hagiwara H, Ueda K, Kanazawa Y, Kasahara A, Fusamoto H, et al. Predicting interferon therapy efficacy from hepatitis C virus genotype and RNA titer. Dig Dis Sci. 1994;39:977-982.

10. Verbaan H, Widell A, Lindgren S, Lindmark B, Nordenfelt E, Eriksson S. Hepatitis C in chronic liver disease: an epidemio- logical study based on 566 consecutive patients undergoing liver biopsy during a 10-year period. J Int Med. 1992;232:33-42.

11. Simmonds P, Zhang LQ, Watson HG, Rebus S, Ferguson ED, Balfe $P$, et al. Hepatitis $C$ quantification and sequencing in blood products, haemophiliacs, and drug users. Lancet. 1990;336:1469-1472.

12. van der Poel CL, Reesink HW, Schaasberg W, LeentvaarKuypers A, Bakker E, Exel-Oehlers PJ, et al. Infective of blood seropositive for hepatitis C virus antibodies. Lancet. 1990; 335:558-560.

13. Yoshioka K, Kakumu S. Predicting factors for the response to interferon therapy against hepatitis $\mathrm{C}$ virus infection: $\mathrm{HCV}$ genotyping. Rinsho Byori. 1994;42:1010-1014.

14. Seong MH, Kil H, Kim YS, Bae SH, Lee YJ, Lee HC, Kang BH, Jeong SH. Clinical and epidemiological features of hepatitis $\mathrm{C}$ virus infection in South Korea: a prospective, multicenter cohort study. J Med Virol. 2013;85:1724-1733.

15. KCDC. Guidelines for viral Hepatitic $\mathrm{C}$ prevention and control [Internet]. Cheonwon: Korea centers for disease control and prevention; 2016 [cited 2018 July 6]. Available from: http://www.cdc.go.kr/CDC/main.jsp. 